\title{
Pembelajaran Akhlak \\ Berbasis Teori Keseimbangan Perilaku Moral
}

\author{
Nunung Nursyamsiah \\ Departemen Pendidikan Bahasa Arab FPBS UPI \\ nsy.ds13@gmail.com
}

\begin{abstract}
This study examines the characteristics of teaching materials that can lead to moral feeling conflict; a classroom activity model that can reinforce moral feeling conflict, followed by a change of moral feeling until the occurrence of an imbalance of moral feeling; and the characteristics of lecture assignments that can encourage the process of internalization of character values and enable the occurrence of the values actualization in student life. The subjects of the study are Arabic Language Education students who take Tahdzibul Akhlaq course in the even semester of 2013/2014. Based on the results of interviews, observations, and documentation of students' muhasabah report, it can be concluded that teaching material with contextual material which is related to the students' life experience has great potential to create moral feeling conflict. The process of reflection in class discussions about the material can create an imbalance of students' moral feelings that triggered the internalization process. Meanwhile, lecture assignments that are able to create internalization of character values productively are field tasks, they are observation of real life from the surrounding environment according to the teaching material and also observation that is related to the life experience of the students so that there is a change of moral feeling.

Keyword: Characteristics of teachng,
\end{abstract}

\section{A. Pendahuluan}

Penelitian Nursyamsiah ${ }^{1}$ yang berfokus pada pengkajian fenomena proses internalisasi nilai-nilai akhlaq untuk mahasiswa Pendidikan Bahasa Arab antara lain menghasilkan sebuah teori baru yang disebut Teori Keseimbangan Perilaku Moral (Akhlaq). Dalam teori tersebut dijelaskan bahwa keseimbangan perilaku moral yang sudah terbentuk lama, ternyata secara bertahap bisa berubah melalui terjadinya momentum perubahan perasaan yang dihasilkan oleh sebuah pengkajian kasus kehidupan (an inspiring case). Ketika sebuah kasus yang diangkat mampu menyentuh perasaan moral seseorang, maka dalam diri orang tersebut terjadi konflik perasaan moral (moral feeling conflict) yang menghasilkan terjadinya keadaan ketidakseimbangan perasaan moral (moral feeling

\footnotetext{
${ }^{1}$ Nursyamsiah, N, "Internalisasi Nilai Akhlaq Melalui Pembelajaran Berbasis Masalah.” (SPs UPI, 2013).
} 
disequilibrium). Jika dalam teori ekuilibrasi kognitif Piaget, keseimbangan baru dapat terjadi melalui proses asimilasi dan akomodasi, dalam teori ini, keseimbangan perilaku moral baru dapat terbentuk melalui proses internalisasi nilai moral melalui tahapan persepsi, interpretasi, eksplorasi, dan refleksi. Jika proses ini mampu menghasilkan keadaan konflik perasaan moral, maka terjadilah momentum perubahan perasaan moral yang mengarah pada terbentuknya keseimbangan perilaku moral baru (aktualisasi nilai moral).

Ditemukannya teori ini merupakan momentum sangat penting untuk ditindaklanjuti melalui penelitian berikutnya yang berfokus pada pengkajian kondisi-kondisi tertentu terkait pembelajaran nilai akhlaq sehingga keberadaan teori tersebut dapat dijelaskan serta dielaborasi kemanfaatannya dalam proses pembelajaran.

\section{B. Metode Penelitian}

Penelitian ini adalah sebuah penelitian kualitatif berkaitan dengan proses pembelajaran nilai-nilai akhlak yang meliputi pengembangan pemahaman dan internalisasi nilai akhlak serta upaya untuk menciptakan kondisi yang dapat mewujudkan terjadinya perubahan perasaan moral mahasiswa sehingga mereka terdorong untuk melakukan perubahan perilaku moral (akhlak) sesuai nilai-nilai yang dikaji. Menurut Ary, Jacobs, dan Sorensen ${ }^{2}$, sebuah penelitian kualitatif tidak lepas kaitannya dengan persoalan konteks dan makna. Penelitian ini, konteks masalah (bahan ajar) yang dihadirkan dalam pembelajaran diambil dari contoh kehidupan para nabi atau sahabat serta contoh kehidupan nyata yang dialami seseorang atau sekelompok orang pada masa kini. Sementara makna yang menjadi fokus perhatian adalah nilai-nilai kehidupan yang merefleksikan nilai akhlak tertentu dan menjadi kajian dalam mata kuliah akhlak di Jurusan Pendidikan Bahasa Arab FPBS UPI. Selain itu, konteks yang menjadi fokus perhatian dalam penelitian ini adalah proses pembelajaran berbasis masalah kehidupan nyata yang memuat nilai-nilai kehidupan (nilai akhlak). Hal yang dilihat dari proses pembelajaran tersebut meliputi perkembangan pemahaman konsep nilai akhlak

\footnotetext{
2 Ary C. D., Jacobs, L.C., \& Sorensen, Introduction to Research in Education (United States:
} Wadsworth Cengage Learning, 2010). 
yang dikaji, proses internalisasi nilai akhlak, serta proses yang mengarah pada terjadinya perubahan perilaku moral (akhlak) tertentu.

Penelitian ini merupakan sebuah penelitian kualitatif yang mempelajari suatu fenomena dalam pembelajaran yakni meliputi proses perkembangan pemahaman konsep nilai akhlak, internalisasi nilai akhlak, serta proses yang mengarah pada terjadinya perubahan perilaku moral (aktualisasi nilai akhlak) tertentu. Ada tiga aspek yang diungkap dalam penelitian ini yaitu karakteristik bahan ajar, model aktivitas kelas, serta model tugas perkuliahan yang dapat mendorong secara efektif terjadinya proses internalisasi nilai-nilai akhlak yang dipelajari serta berpeluang untuk memperkuat dorongan kearah aktualisasi nilainilai tersebut. Diagram 1 berikut ini menggambarkan tahapan aktivitas penelitian yang dilakukan.

\section{Diagram 1 Tahapan Aktivitas Penelitian}

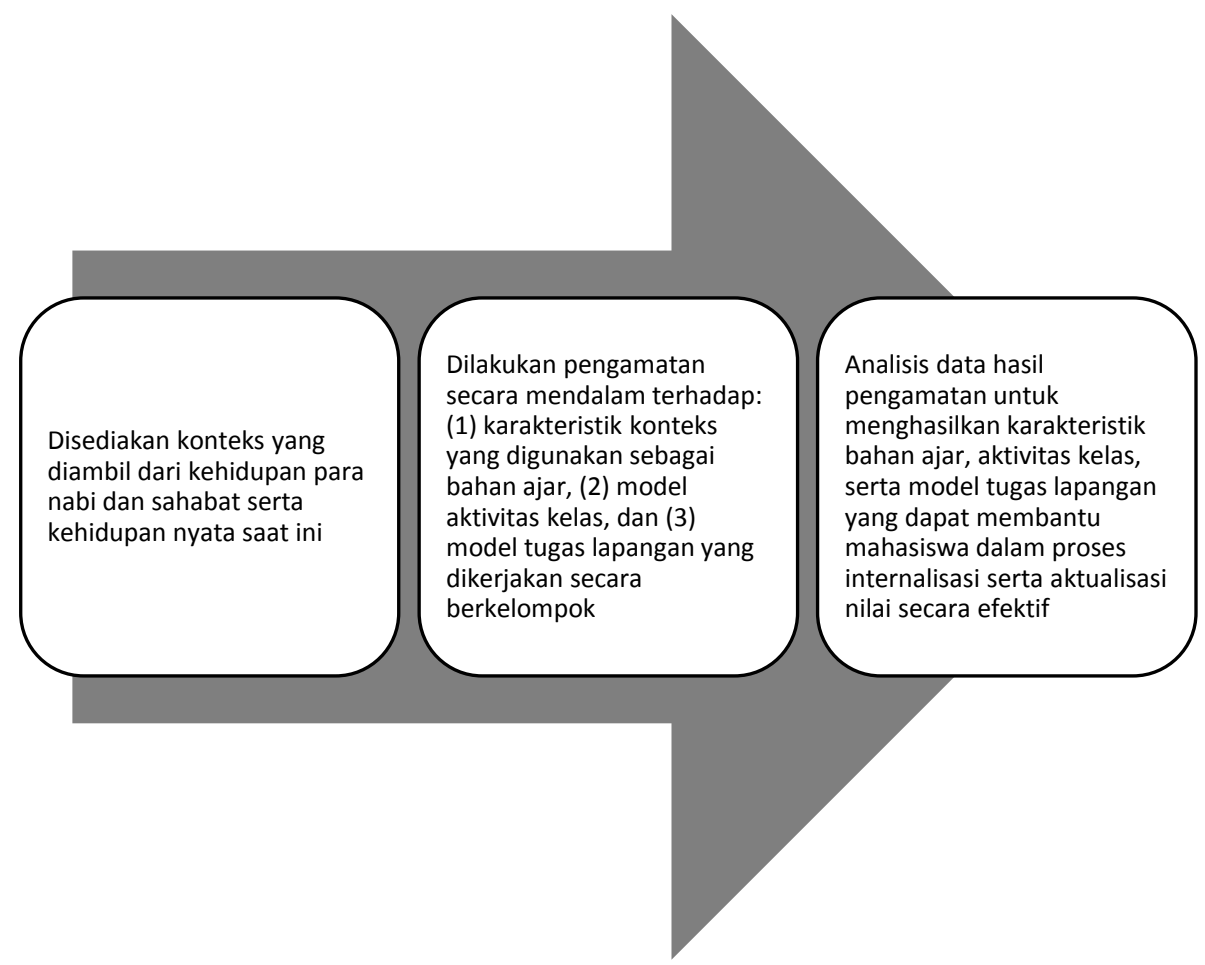

Untuk menjamin aspek credibility (nilai kebenaran data), dependability (konsistensi data penelitian), transferability (kemungkinan untuk generalisasi), dan confirmability (netralitas) dalam penelitian ini dilakukan langkah-langkah 
sesuai yang disarankan $\mathrm{Charmaz}^{3}$, yaitu didasarkan atas pertanyaan-pertanyaan berikut: (1) apakah peneliti memiliki data yang cukup diandalkan mengenai subyek, proses, dan konteks dalam kaitannya dengan penelitian yang dilakukan?; (2) apakah peneliti memiliki deskripsi data yang cukup rinci tentang pandangan dan aksi subyek?; (3) apakah data yang diperoleh mengandung informasi yang mendalam tentang konteks dan makna yang diamati?; (4) apakah data yang dimiliki cukup untuk mengamati perubahan-perubahan yang terjadi?; (5) apakah peneliti memiliki pandangan beragam tentang aspek yang diamati dari subyek penelitian?; (6) apakah peneliti sudah memperoleh data yang memungkinkan untuk mengembangkan kategori analitis?; dan (7) perbandingan apa yang bisa dibuat antar data yang terkumpul?, serta bagaimana perbandingan tersebut menghasilkan suatu kesimpulan sebagaimana yang diharapkan peneliti?.

\section{Kajian Pustaka}

Secara alamiah belajar melibatkan aktivitas seperti observasi, mendengar, dan membaca. Proses ini akan menghasilkan persepsi mental tentang apa yang diobservasi, didengar atau dibaca. Persepsi mental ini tidak bersifat statis, karena setiap orang tentu memiliki pengetahuan, dan pengalaman sebelumnya yang terkait dengan persepsi mental tersebut. Akibatnya, pada diri seseorang yang belajar akan terjadi proses aksi mental berupa pengaitan antar obyek-obyek mental lama yang tersimpan dalam memori jangka panjang serta persepsi mental yang baru terbentuk. Proses ini kemudian dimaknai sebagai berpikir yang pada akhirnya akan menghasilkan obyek mental baru antara lain berupa deskripsi dan pemahaman tentang hal yang dipelajari.

Konteks belajar nilai, aktivitas itu tidak hanya melibatkan proses mental melainkan juga perasaan. Proses olah rasa tidak berdiri sendiri melainkan ada kaitannya dengan pemahaman tentang nilai yang dipelajari, dan perpaduan dari kedua proses tersebut akan menghasilkan sikap baru yang dalam jangka tertentu bisa memicu terjadinya perilaku moral (nilai) baru. Dunia pendidikan, sebagaimana yang diungkapkan UNESCO memberikan contoh pilar yakni kebiasaan hidup bersama, saling menghargai, terbuka, memberi dan

\footnotetext{
${ }^{3}$ Ibid.
} 
menerima pada masyarakat yang pluralis dengan keragaman ras, suku, agama/keyakinan dan budaya. ${ }^{4}$ Sebagai contoh, ketika seseorang belajar tentang syukur maka upaya yang dilakukan melalui proses membaca, mendengar penjelasan orang lain, atau mengkaji contoh perilaku orang yang bersyukur, maka proses persepsi dan aksi mental yang menghasilkan obyek mental baru terjadi bersamaan dengan proses olah rasa sehingga memunculkan sikap atau keyakinan baru tentang makna syukur tersebut. Proses tersebut diilustrasikan melalui gambar 1 berikut ini.

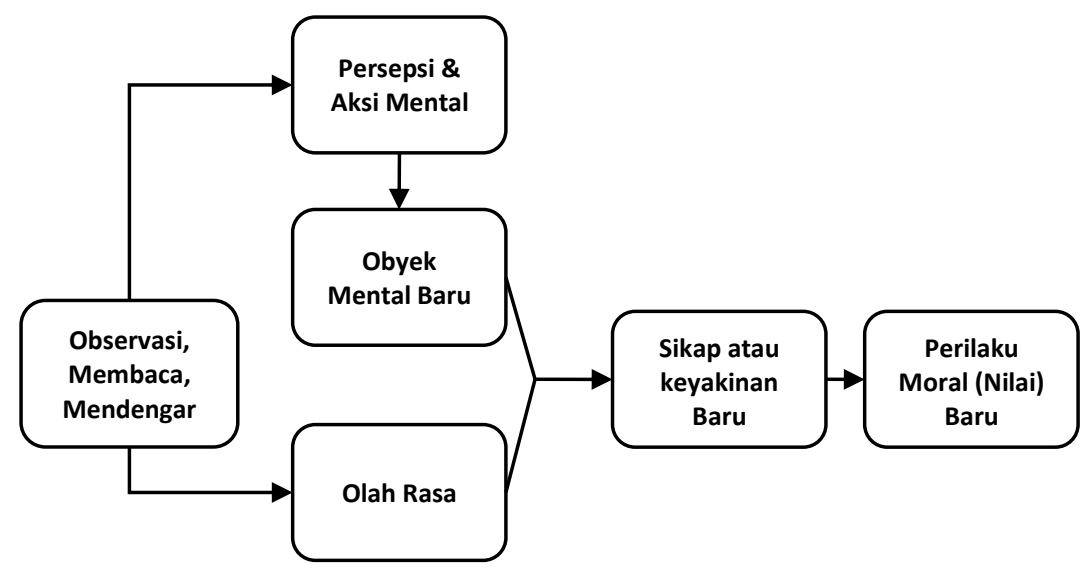

\section{Gambar 1. Proses Pembentukan Keyakinan dan Perilaku Moral Baru}

Proses pembentukan keyakinan yang menjadi pemicu terjadinya perilaku moral baru di atas, dikembangkan berdasarkan teori Lickona $^{5}$ tentang perkembangan perilaku moral yang dibentuk melalui tahapan moral knowing, moral feeling, dan moral behavior. Pada gambar 1, pembentukan obyek mental baru (moral knowing) terjadi secara simultan dengan olah rasa (moral feeling) sehingga pada waktu bersamaan akan terjadi proses penghayatan nilai (internalisasi nilai) yang dipelajari yang dapat menjadi pendorong terjadinya perilaku moral atau nilai baru (moral behavior).

${ }^{4}$ Erawati, D. (2017). Peranan Sosialisasi Nilai Kebersamaan Dalam Upaya Menanggulangi Konflik Beragama Dalam Kehidupan Bermasyarakat Di Kota Palngka Raya. Palita: Journal of Social-Religion Research, 2(1), 1-14.

${ }^{5}$ Lickona T, Educating for Character: How Our Schools Can Teach Respect Respect and Responsibility (Jakarta: Bumi Aksara, 2012). 
Proses terbentuknya obyek-obyek mental baru tidaklah terjadi dengan sendirinya melainkan melalui suatu proses yang dapat dijelaskan melalui sebuah teori dari Piaget ${ }^{6}$ yaitu teori keseimbangan kognitif (cognitive equilibrium). Dalam teori ini dijelaskan bahwa belajar diawali oleh konflik kognitif yang memicu terjadinya ketidakseimbangan kognitif atau disekuilibrasi. Terjadinya keadaan tersebut dapat dicirikan oleh munculnya rasa ingin tahu, pertanyaan, kebingungan, serta upaya untuk mendapatkan kejelasan melalui suatu proses yang disebut oleh Piaget sebagai proses asimilasi. Proses ini bisa dilakukan melalui aktivitas belajar seperti membaca lebih jauh tentang apa yang dipertanyakan atau yang menjadi rasa penasaran, serta bertanya atau berdiskusi dengan orang lain sehingga pada akhirnya terbentuk pemahaman baru yang oleh Piaget disebut sebagai proses akomodasi (terbentuknya obyek mental baru).

Terbentuknya obyek mental baru di atas, dapat dijelaskan secara proses kognitif sebagai berikut. Ketika seseorang dihadapkan pada suatu tugas akademik seperti membaca, mendengar penjelasan, atau melakukan observasi, maka terjadi proses persepsi mental, yang diikuti proses aksi mental yakni pengaitan antara persepsi mental yang baru terjadi dengan pengetahuan atau pengalaman sebelumnya berbentuk obyek-obyek mental lama yang tersimpan dalam memori jangka panjang. Jika obyek-obyek mental yang ada tidak mampu menjelaskan tentang apa yang dipikirkan sebagai akibat dari proses belajar yang dilakukan, maka terjadilah konflik kognitif. Apabila proses ini dilanjutkan melalui proses lain seperti membaca lebih lanjut, bertanya, atau berdiskusi dengan pihak lain, maka informasi, penjelasan, atau argumentasi tersebut masuk ke dalam struktur mental yang sedang berproses (asimilasi), dan selanjutnya terbentuklah pemahaman baru (akomodasi).

Penjelasan yang didasarkan pada teori Piaget di atas, belum menggambarkan tentang kapan proses belajar terjadi pada level individu dan kapan terjadi pada interaksi sosial. Menurut teori Zone of Proximal Development

\footnotetext{
${ }^{6}$ Piaget J., The Development of Thought: Equilibration of Cognitive Structures. (Oxford: Basil Blackwell., 1978).
} 
$(Z P D)$ dari Vigotsky ${ }^{7}$, belajar terjadi pada dua tahap yakni tahap individual dan tahap interaksi sosial. Capaian yang diperoleh melalui tahap belajar secara individual disebut tahap perkembangan aktual (actual development). Tahap ini dicirikan oleh adanya kemampuan baru yang dicapai melalui upaya sendiri. Namun demikian, kemampuan yang dicapai melalui upaya sendiri tersebut sebenarnya belum bersifat optimal, misalnya, ada bagian-bagian dari yang dipelajari belum bisa dijelaskan secara lebih baik, atau masih ada aspek yang dipelajari menyisakan pertanyaan-pertanyaan yang belum bisa dijawab. Dalam keadaan seperti ini, maka seseorang yang belajar membutuhkan pihak lain (teman belajar atau dosen) untuk berinteraksi melalui tanya-jawab atau berdiskusi. Dari proses seperti ini, tentu dicapai suatu kemampuan baru lebih baik atau lebih tinggi yang oleh Vigotsky disebut sebagai tahap perkembangan potensial (potential development). Jarak antara kedua tahapan perkembangan tersebut, yakni antara perkembangan aktual dan perkembangan potensial oleh Vigotsky disebut sebagai Zone of Proximal Development (ZPD).

Berdasarkan teori $Z P D$ tersebut, maka proses pembentukan keyakinan baru (internalisasi nilai) yang mengarah pada pembentukan perilaku moral baru sebagaimana digambarkan pada Gambar 2, dapat dimodifikasi seperti pada gambar Gambar 2.

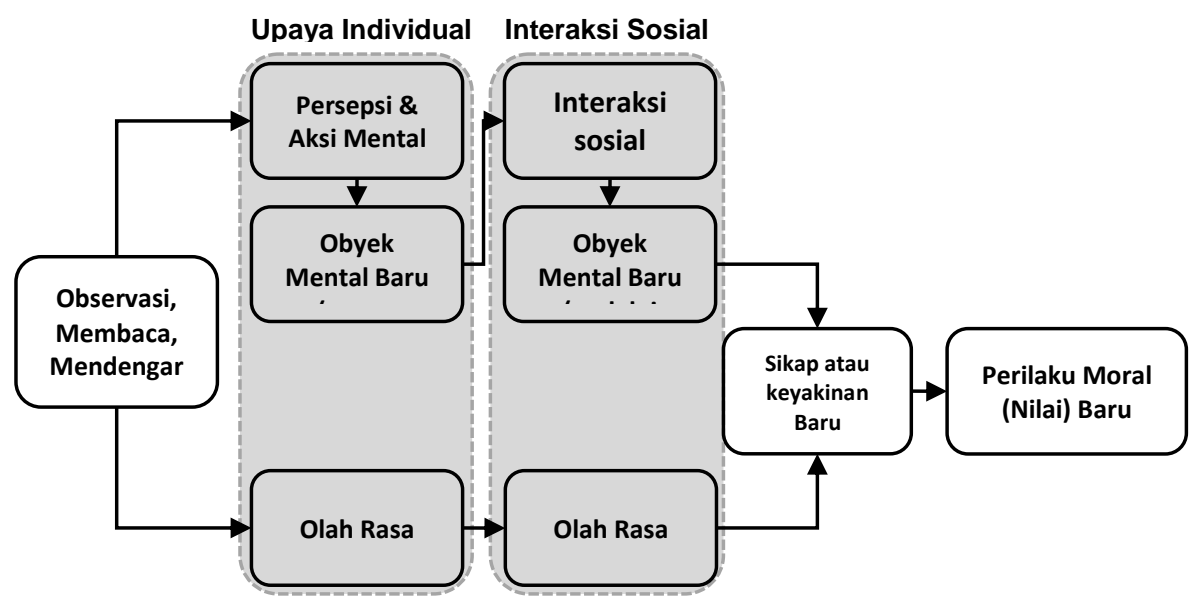

Gambar 2. Proses Pembentukan Keyakinan dan Perilaku Moral Baru

\footnotetext{
${ }^{7}$ Vigotsky L.S., Mind in Society: The Development of Higher Psychological Processes. Dalam M. Cole, V. John-Steiner, S. Scribner, \& E. Souberman (Cambridge: Harvard University Press, 1978).
} 
Proses belajar sebagaimana dijelaskan melalui diagram gambar 2, sebenarnya tidak hanya terjadi satu siklus melainkan terus berlanjut sehingga siklus belajar tersebut terjadi berulang-ulang. Dengan kata lain, tahap pencapaian aktual dan potensial sebenarnya tidak hanya terjadi satu kali melainkan terjadi berkali-kali seiring dengan berulangnya upaya-upaya yang dilakukan baik secara invidual maupun dalam interaksi sosial.

Penyajian substansi yang dipelajari, belajar tidak hanya terjadi dari proses membaca atau mendengar penjelasan pihak lain, melainkan bisa melalui sajian contoh teladan baik yang diambil dari sejarah maupun contoh masalah kehidupan sehari-hari yang berlangsung saat ini. Proses belajar ini dapat dijelaskan oleh teori reinfocement dari Hill $^{8}$ yang antara lain menjelaskan bahwa manusia pada dasarnya memiliki kecenderungan untuk terinspirasi pihak lain sehingga berusaha untuk meniru (Primary Reinforcement). Dengan demikian, menghadirkan contoh-contoh inspiratif dan bisa menjadi model, merupakan hal penting dalam proses belajar. Dalam konteks belajar nilai-nilai akhlak, contoh tersebut bisa diambil dari masalah kehidupan masa lalu seperti perilaku para nabi dan sahabat yang tersedia dalam buku-buku sejarah, atau diambil dari masalah kehidupan nyata saat ini yakni berupa perilaku seseorang atau sekelompok orang yang ada di sekitar kehidupan mahasiswa. Ketika contoh-contoh tersebut tersebut dibahas di kelas serta dilakukan eksplorasi melalui identifikasi contoh-contoh lain yang sesuai dengan pengalaman hidup atau hal serupa yang pernah dijumpai mahasiswa, maka akan terjadi penguatan lebih lanjut yang oleh $\mathrm{Hill}^{9}$ disebut dengan Vicarious Reinforcement.

Sebagaimana dinyatakan sebelumnya, bahwa yang menjadi fokus pengamatan utama penelitian ini adalah proses internalisasi nilai akhlak. Hasil penelitian Deci, Eghrari, Patrick, dan Leona ${ }^{10}$, menunjukkan bahwa terdapat dua jenis internalisasi yakni yang bersifat introjeksi (introjection) dan intergrasi

\footnotetext{
${ }^{8}$ Hill W.F., Learning Theory and the Acquisition of Values. Psychological Review, 1960, 317331.

${ }^{9}$ Ibid.

${ }^{10}$ Deci D.R. E.L., Eghrari, H., Patrick, B.C., dan Leone, Facilitating Internalization: The SelfDetermination Theory Perspective. Journal of Personality, 1994, 120-142.
} 
(integration). Tipe internalisasi pertama dapat dikembangkan berdasarkan proses pembiasaan dalam waktu yang cukup, sementara tipe kedua dapat berkembang melalui keterlibatan pemahaman dan perasaan mendalam tentang suatu nilai. Selain itu, penelitian mereka juga menemukan tiga faktor kontekstual yang dapat memfasilitasi terjadinya internalisasi yaitu dengan menyediakan argumentasi bermakna, mengakui atau mengungkap perasaan peserta didik, dan menyediakan pilihan. Penelitian lain seperti yang dilakukan oleh Martinez, dan Garcia ${ }^{11}$, mengungkap aspek lain dari proses internalisasi. Penelitian ini menemukan bahwa bukan hanya aspek konteks yang berpengaruh terhadap proses internalisasi nilai, melainkan juga gaya personal yang membawa nilai tersebut. Dengan demikian, dari dua penelitian ini dapat disimpulkan bahwa konteks dan personal yang menjadi acuan untuk terjadinya proses internalisasi nilai memegang peran yang sangan penting.

\section{Pembahasan}

Bagian ini menjelaskan temuan kajian dan pembahasannya sesuai pertanyaan penelitian yang diajukan. Sebagaimana dungkapkan sebelumnya, penelitian ini berusaha menjawab tiga pertanyaan berikut: (1) Bagaimana karakteristik bahan ajar yang dapat menimbulkan terjadinya konflik perasaan moral sebagaimana yang dijelaskan dalam teori keseimbangan perilaku moral?, (2) Model aktivitas belajar seperti apa yang dapat memperkuat terjadinya konflik perasaan moral, diikuti dengan perubahan perasaan moral, sehingga terjadi ketidakseimbangan perasaan moral?, dan (3) Bagaimana karakteristik tugas-tugas perkuliahan yang dapat mendorong terjadinya proses internalisasi nilai-nilai akhlak serta memungkinkan terjadinya aktualisasi nilai tersebut dalam kehidupan mahasiswa?

\section{Karakteristik Bahan Ajar}

Bahan ajar yang digunakan dalam pembelajaran akhlak diambil dari contoh-contoh teladan berdasarkan sejarah kehidupan para nabi atau sahabat, dan dari kehidupan sehari-hari yang diperoleh melalui pengamatan langsung oleh para

${ }^{11}$ Martinez J.F. I., dan Garcia, Internalization of Values and Self-Esteem Among Brazilian Teenagers from Authoritative, Indulgent, Authoritarian, and Neglectful Homes. Adolescence, 2008, 13-29. 
mahasiswa secara berkelompok. Teladan yang diambil dari kehidupan para nabi atau sahabat digunakan selain untuk menggali nilai-nilai sesuai dengan nilai akhlak yang dikaji, juga untuk mendorong terjadinya konflik perasaan moral. Sebagai contoh, pada saat belajar tentang nilai cinta dan ridla teladan yang ditampilkan adalah kehidupan seorang sufi terkenal yaitu Robi'ah Al Adawiyah pada peristiwa ziarah ke makam Rasulullah. Pada peristiwa itu, sufi tersebut menyatakan "maafkan aku ya Rasulullah, bukan aku tidak mencintaimu tapi hatiku telah tertutup untuk cinta yang lain karena telah penuh cintaku pada Allah". Ungkapan ini selain bersifat puitis juga bermakna simbolis bahwa cinta kepada Allah adalah bentuk integrasi dari semua bentuk cinta termasuk kepada Rasulullah. Dengan kata lain jika seseorang mencintai Allah dengan sepenuh hati mengandung arti yang bersangkutan mencintai apa yang dicintai Allah, termasuk kepada Rasulullah. Dari hasil penelitian yang dilakukan, contoh seperti ini memberikan makna dan inspirasi mendalam tentang nilai cinta hakiki. Dari diskusi yang dilakukan di kelas, terungkap fakta bahwa mahasiswa sangat terinspirasi hal ini. Contoh ungkapan mahasiswa yang membuktikan hal tersebut antara lain, "jika kita mencintai seseorang berarti kita juga harus mencintai orangorang yang dicitintainya".

Memaknai cinta dan ridla juga dilakukan mahasiswa melalui penelusuran peristiwa dalam kehidupan nyata saat ini. Contoh yang berhasil diangkat mahasiswa berkenaan dengan nilai tersebut adalah peristiwa tukang tembok atau pekerja bangunan. Dalam peristiwa ini diceritakan bahwa ketika pekerja tersebut sedang melaksanakan tugasnya, disekitar tempat itu terdapat banyak pot bunga. Hawatir terjadi apa-apa dengan barang tersebut, sebelum melakukan pekerjaannya semua pot bunga dipindahkan serta dibereskan ke tempat lain dan setelah pekerjaannya selesai semuanya dikembalikan ke tempat asal. Ketika mahasiswa bertanya kepada yang bersangkutan, mengapa hal itu dilakukan, padahal bukan tugasnya, tukang tembok menjelaskan bahwa hal itu dilakukan semata-mata karena Allah. Peristiwa semacam ini sangat inspriratif bagi mahasiswa, sehingga dalam diskusi kelas setelah video peristiwa ini ditayangkan, terungkap sejumlah pernyataan mahasiswa yang cukup menarik. Di antara ungkapan tersebut adalah, 
"Melakukan sesuatu hanya karena Allah berarti bahwa hanya Allah yang memiliki cinta dan ridla hakiki. Dengan hanya mengharapkan cinta dan ridla Allah, berarti ada keyakinan pada orang tersebut bahwa Allah juga cinta dan ridla terhadap siapapun yang dikehendakinya termasuk kepada pemilik pot bunga yang dia bereskan. Maka dengan cinta dan ridla Allah, kebaikan akan kembali terpulang kepada tukang tembok, dari manapun datangnya sesuai kehendak Allah.” Dua peristiwa ini, selain mampu mengungkap makna mendalam tentang nilai cinta dan ridla juga berhasil membuka mata hati para mahasiswa yang merasa tergugah dengan peristiwa tersebut. Hal ini terungkap dari muhasabah yang dilakukan mahasiswa serta hasil wawancara pendalaman, yang menunjukkan bahwa telah terjadi proses konflik parasaan moral yang mampu mendorong terjadinya internalisasi nilai cinta dan ridla.

Dua contoh peristiwa yang dikemukakan di atas, ditemukan tiga karakteristik utama yang harus dipenuhi materi ajar, yaitu mampu mengungkap makna secara mendalam tentang nilai yang dikaji, dapat menggugah mahasiswa yakni membuka mata hati dan perasaan mereka, serta menginspirasi yakni mampu mendorong mahasiswa untuk mengaktualisasikan nilai yang dipelajari dalam kehidupan mereka sehari-hari.

\section{Model Aktivitas Belajar}

Aktivitas belajar yang dilakukan mahasiswa meliputi pencarian contoh teladan bersumber dari sejarah para nabi dan sahabat yang relevan dengan nilai akhlak yang dipelajari, menelusuri contoh dari kehidupan sehari-hari, menuangkan contoh-contoh tersebut secara tertulis dan melalui video, menyajikan atau menayangkan peristiwa yang terpilih oleh para mahasiswa di kelas, melakukan diskusi dan refleksi atas apa yang disajikan dan atau ditayangkan, serta melakukan muhasabah individual secara tertulis. Upaya pengungkapan makna mendalam tentang nilai-nilai akhlak yang dipelajari, dilakukan melalui pencarian contoh relevan dari peristiwa sejarah para nabi dan sahabat serta dari peristiwa kehidupan nyata seahari-hari. Upaya tersebut diungkapkan secara tertulis dan video peristiwa terpilih. Ungkapan tertulis serta video tersebut kemudian disajikan dalam kegiatan perkuliahan, yang diikuti dengan diskusi dan refleksi atas konsep 
atau makna nilai serta peristiwa terkait yang disajikan. Rangkaian aktivitas belajar tersebut, diakumulasikan melalui kegiatan muhasabah individual. Muhasabah ini selain menggambarkan sejauh mana pemahaman atas makna nilai-nilai akhlak yang dipelajari, juga mampu mengungkapkan jenis aktivitas belajar, serta teladan dan peristiwa kehidupan yang dapat memicu terjadinya ketidak seimbangan perasaan moral yang diikuti perubahan perasaan moral serta ditindaklanjuti upaya mahasiswa mengaktualisasikan nilai akhlak tertentu dalam kehidupan seaharihari.

Data-data penelitian yang ada, didapat gambaran bahwa dari rangkaian proses belajar sebagaimana dipaparkan di atas, ditemukan bahwa aktivitas diskusi dan refleksi mengikuti aktivitas penyajian makna nilai serta contoh teladan dari fakta sejarah dan kehidupan nyata dapat menjadi wahana kondusif bagi mahasiswa mengalami peristiwa penting yakni terjadinya ketidakseimbangan perasaan moral. Kejadian-kejadian penting yang mengindikasikan terjadinya hal tersebut antara lain berupa keterlibatan mahasiswa yang sangat aktif, mengungkapkan makna nilai secara mendalam serta penuh perasaan, serta refleksi atas nilai yang dikaji melalui penggunaan perspektif pengalaman masing-masing. Dalam kegiatan seperti ini tidak jarang mahasiswa sangat tersentuh perasaannya sehingga tak mampu menahan keluarnya air mata.

\section{Karakteristik Tugas Lapangan}

Tugas lapangan yang dilakukan mahasiswa meliputi penelusuran peristiwa kehidupan nyata dari masyarakat yang sesuai dengan nilai-nilai akhlak yang dikaji. Dalam perkuliahan kali ini pristiwa yang diangkat antara lain kehidupan pemulung, pekerja bangunan, satpam, mahasiswa penjaja makanan, penjual makanan ringan di terminal Ledeng, serta orang cacat yang penuh semangat dan berbakti pada orang tua. Selain memotret keseharian dari contoh kehidupan orang tersebut melalui rekaman video, mahasiswa juga melakukan wawancara terhadap yang bersangkutan. Video dan hasil wawancara ini kemudian ditayangkan pada perkuliahan, dibahas dan didiskusikan, dan diakhiri dengan refleksi oleh masingmasing mahasiswa. 
Pengamatan yang diperoleh dari observasi kelas tersebut, ditemukan karakteristik tugas yang mampu menciptakan ketidakseimbangan perasaan moral mahasiswa antara lain meliputi contoh kongkret dengan karakteristik adanya kesesuaian dengan keyakinan sendiri sehingga memperkuat pemahaman dan perilaku sehari-hari, atau bertentangan dengan kebiasaan sehari-hari yang dilakukan mahasiswa dalam kehidupannya. Ketika mahasiswa menemukan peristiwa yang ada kesesuaian dengan keyakinan atas aktualisasi nilai akhlak tertentu, dampak yang terjadi adalah penguatan terhadap keyakinan serta upaya aktualisasi nilai tersebut. Apabila peristiwa yang diamati bertentangan dengan kebiasaan mahasiswa dalam kehidupannya, maka dampak yang terjadi adalah ketidakseimbangan perilaku moral yang diikuti perubahan perasaan moral. Dari muhasabah yang dilakukan mahasiswa, banyak contoh yang menunjukkan bahwa mereka berhasil mengubah kebiasaannya diakibatkan proses belajar yang telah dilalui khususnya setelah mengkaji peristiwa kehidupan yang dicontohkan serta dibahas di kelas.

\section{E. Kesimpulan}

Penelitian ini mengkaji karakteristik bahan ajar yang dapat menimbulkan terjadinya konflik perasaan moral; model aktivitas kelas yang dapat memperkuat terjadinya konflik perasaan moral, diikuti perubahan perasaan moral hingga terjadi ketidakseimbangan perasaan moral; dan karakteristik tugas-tugas perkuliahan yang dapat mendorong terjadinya proses internalisasi nilai-nilai akhlaq serta memungkinkan terjadinya aktualisasi nilai tersebut dalam kehidupan mahasiswa. subyek penelitiannya adalah mahasiswa Pendidikan Bahasa Arab peserta matakuliah Tahdzibul Akhlaq pada semester genap tahun 2013/2014. Berdasarkan hasil wawancara, observasi, dan studi dokumentasi laporan muhasabah mahasiswa disimpulkan bahwa bahan ajar dexngan materi kontekstual berkaitan dengan pengalaman hidup mahasiswa berpotensi besar menimbulkan konflik perasaan moral. Proses refleksi dalam diskusi kelas tentang materi tersebut terbukti dapat menciptakan ketidakseimbangan perasaan moral mahasiswa yang memicu terjadinya proses internalisasi. Sementara itu, tugas-tugas perkuliahan yang mampu menciptakan internalisasi nilai akhlaq secara produktif adalah tugas 
lapangan yakni pengamatan kehidupan nyata dari lingkungan sekitar sesuai materi serta terkait pengalaman hidup mahasiswa sehingga terjadi perubahan perasaan moral.

\section{Daftar Pustaka}

C., Ary, D., Jacobs, L.C., \& Sorensen,. Introduction to Research in Education. United States: Wadsworth Cengage Learning, 2010.

D.R., Deci, E.L., Eghrari, H., Patrick, B.C., dan Leone,. Facilitating Internalization: The Self-Determination Theory Perspective. Journal of Personality, 1994.

J., Piaget. The Development of Thought: Equilibration of Cognitive Structures. Oxford: Basil Blackwell., 1978.

J.F., Martinez, I., dan Garcia,. Internalization of Values and Self-Esteem Among Brazilian Teenagers from Authoritative, Indulgent, Authoritarian, and Neglectful Homes. Adolescence, 2008.

L.S., Vigotsky. Mind in Society: The Development of Higher Psychological Processes. Dalam M. Cole, V. John-Steiner, S. Scribner, \& E. Souberman. Cambridge: Harvard University Press, 1978.

Nursyamsiah, N. "Internalisasi Nilai Akhlaq Melalui Pembelajaran Berbasis Masalah." SPs UPI, 2013.

T, Lickona. Educating for Character: How Our Schools Can Teach Respect Respect and Responsibility. Jakarta: Bumi Aksara, 2012.

W.F., Hill. Learning Theory and the Acquisition of Values. Psychological Review, 1960. 